\title{
Role of Insurance Sector on Inclusive Growth in India
}

\author{
Debabrata Jana
}

Bankura Sammilani College, T.G.Samanta Road, Kenduadihi, Bankura, West Bengal 722102, India

\begin{tabular}{|c|c|}
\hline ARTICLE INFO & A B S T RACT \\
\hline $\begin{array}{l}\text { Keywords: } \\
\text { Insurance, } \\
\text { Premium, } \\
\text { Claim, } \\
\text { Investment, } \\
\text { GDP } \\
\\
\text { Kata Kunci: } \\
\text { Auransi, } \\
\text { Premi, } \\
\text { Klaim, } \\
\text { Investasi, } \\
\text { PDP }\end{array}$ & $\begin{array}{l}\text { In the present era insurance sector plays a vital role in both developed } \\
\text { and developing countries. Insurance markets working as a financial } \\
\text { intermediary to contribute economic growth of the country as well } \\
\text { as risk management more efficiently. The purpose of the study is to } \\
\text { investigate the relationship between insurance sector development } \\
\text { and economic growth in India. For this study, data has been collected } \\
\text { only from the secondary sources for the period } 2000 \text { to } 2019 \text {. To run } \\
\text { linear regression, four variables are taken viz. GDP as a surrogate of } \\
\text { economic growth and Real Premium Growth Rate, Total Investment } \\
\text { in Insurance Sector and Insurance Claim. Finally, it can be suggested } \\
\text { that more attention in the insurance market is to be paid so that proper } \\
\text { economic growth will be possible in the developing country in India. }\end{array}$ \\
\hline
\end{tabular}

\section{SARI PATI}

Pada era sekarang sektor asuransi memegang peranan yang sangat vital baik dalam negara yang sedang dan negara berkembang. Pasar asuransi bekerja sebagai keuangan perantara yang berkontribusi pada pertumbuhan ekonomi negara juga karena manajemen risiko lebih efisien. Tujuan dari penelitian ini adalah untuk menyelidiki hubungan antara pengembangan sektor asuransi dan pertumbuhan ekonomi di India. Untuk studi ini, data telah dikumpulkan hanya dari sumber sekunder untuk periode 2000 hingga 2019. Untuk dijalankan regresi linier, empat variabel diambil yaitu $P D B$ sebagai pengganti pertumbuhan ekonomi dan Tingkat Pertumbuhan Premi Riil, Total Investasi Bidang Asuransi dan Klaim Asuransi. Akhirnya, itu bisa disarankan bahwa lebih banyak perhatian di pasar asuransi harus diberikan sehingga layak pertumbuhan ekonomi akan mungkin terjadi di negara berkembang di India. 


\section{INTRODUCTION}

In the present era insurance sector plays a vital role in both developed and developing countries. Insurance markets working as a financial intermediary to contribute economic growth of the country as well as risk management more efficiently. Actually the economic growth of any country depends of the involvement of financial intermediaries. This involvement includes the provision for reimbursement and settling payments to facilitate the exchange of goods and services, resource allocation by mobilizing surplus fund to deficit sectors, risk management, price information to the general pupils for proper decision making in various sectors of the economy. Insurance sector not only provides the risk management of any human life it also covers various non-life sectors of the economy like industrial, health, fire, transportation, agricultural, mining, marine, etc. Insurance sector generally divided as life insurance, non-life insurance and reinsurance. Life insurance represents the long-term contract in the form of investment on the other hand the non-life insurance represents short-term contract in the form of indemnity. Reinsurance means to mitigation the risk by transfer to other parties with some agreements for collection of losses. However, existing literatures show that insurance development significantly affect the economic growth At present, insurance sector of India consists of 59 insurance companies of which 24 are in life insurance business and rest 35 are non-life insurers including reinsurance (source: IRDA). In case of life insurers, only Life Insurance Corporation (LIC) plays as a public sector company. In case of non-life insurance sector six public players working in India.

\section{Insurance Density and Penetration in India:}

For better understanding of insurance sector development towards inclusive growth two main parameters as insurance density and insurance penetration of both life as well as non-life insurance

Tabel 1. Life and Non-Life Insurance Density and Penetration in India

\begin{tabular}{lcccccc}
\hline \multirow{2}{*}{ Year } & \multicolumn{2}{c}{ Life } & \multicolumn{2}{c}{ Non-Life } & \multicolumn{2}{c}{ Industry } \\
\cline { 2 - 7 } & $\begin{array}{c}\text { Density (in } \\
\text { USD) }\end{array}$ & $\begin{array}{c}\text { Penetration } \\
\text { (in \%) }\end{array}$ & $\begin{array}{c}\text { Density (in } \\
\text { USD) }\end{array}$ & $\begin{array}{c}\text { Penetration } \\
\text { (in \%) }\end{array}$ & $\begin{array}{c}\text { Density (in } \\
\text { USD) }\end{array}$ & $\begin{array}{c}\text { Penetration } \\
\text { (in \%) }\end{array}$ \\
\hline 2001 & 9.10 & 2.15 & 2.40 & 0.56 & 11.50 & 2.71 \\
\hline 2002 & 11.70 & 2.59 & 3.00 & 0.67 & 14.70 & 3.26 \\
\hline 2003 & 12.90 & 2.26 & 3.50 & 0.62 & 16.40 & 2.88 \\
\hline 2004 & 15.70 & 2.53 & 4.00 & 0.64 & 19.70 & 3.17 \\
\hline 2005 & 18.30 & 2.53 & 4.40 & 0.61 & 22.70 & 3.14 \\
\hline 2006 & 33.20 & 4.10 & 5.20 & 0.60 & 38.40 & 4.80 \\
\hline 2007 & 40.40 & 4.00 & 6.20 & 0.60 & 46.60 & 4.70 \\
\hline 2008 & 41.20 & 4.00 & 6.20 & 0.60 & 47.40 & 4.60 \\
\hline 2009 & 47.70 & 4.60 & 6.70 & 0.60 & 54.30 & 5.20 \\
\hline 2010 & 55.70 & 4.40 & 8.70 & 0.71 & 64.40 & 5.10 \\
\hline 2011 & 49.00 & 3.40 & 10.00 & 0.70 & 59.00 & 4.10 \\
\hline 2012 & 42.70 & 3.17 & 10.50 & 0.78 & 53.20 & 3.96 \\
\hline 2013 & 41.00 & 3.10 & 11.00 & 0.80 & 52.00 & 3.90 \\
\hline 2014 & 44.00 & 2.60 & 11.00 & 0.70 & 55.00 & 3.30 \\
\hline 2015 & 43.20 & 2.72 & 11.50 & 0.72 & 54.70 & 3.44 \\
\hline 2016 & 46.50 & 2.72 & 13.20 & 0.77 & 59.70 & 3.49 \\
\hline 2017 & 55.00 & 2.76 & 18.00 & 0.93 & 73.00 & 3.69 \\
\hline 2018 & 55.00 & 2.74 & 19.00 & 0.97 & 74.00 & 3.70 \\
\hline
\end{tabular}

Source: IRDA 
are given in the following table below. Insurance density is calculated as a proportion of premium to total population and Insurance penetration is calculated as proportion of premium to GDP.

From the above table, it is noticed that life insurance density and total insurance density is tremendous increased from 9.10 (2001) to 55.70 (2010) then after slowly decreasing to the year 2013 and then after increase. Whereas non-life insurance density gradually increasing trend from 2.40 (2001) to 19.00 (2018). So, it can be said that life insurance and total insurance density has same picture availed in contrast to non-life insurance density. Another variable namely insurance penetration shows that also the same as life insurance density and total insurance density.

\section{LITERATURE REVIEW}

Some important studies which the author has come across are mentioned below.

Ghosal (2012) examines the role of insurance for economic development of India. Author noticed that the insurance sector is on the edge for huge growth by way of number of policy holders, policy premium, new product and increased technology focus. Nejad and Kermani (2012) examine the relation between insurance sector development and economic growth in Iran. As per results of the investigation, the researcher there is a unidirectional causality relation between insurance sector development and economic growth. Zouhaier (2014) looks into the relationship between the insurance business and the economic growth of 23 OECD countries. Researcher reveals that positive impact of non-life insurance on penetration rate on economic growth and a reverse effect of total insurance and non-life insurance to the density on economic growth. Singh and Gangal (2015) examines the growth and the role of micro insurance in poverty inequality removal. Researcher suggests that for effective development of micro insurance different awareness programme conducted like literacy awareness camp, flexibility in premium collection, encouraging savings and inflow of foreign capital by way of private investment. Olayungbo (2015) pursue the effects of life and non-life insurance on economic growth in Nigeria. Author exhibits that the long run relationship exists among economic life, non-life insurance and economic growth. Phutkaradze (2015) investigate the development of an insurance market is linked to economic growth. Author depicts that negative and non-significant correlation between insurance and GDP growth in post-transition economies. Buric et al. (2017) unlock the most significant factors that influence on life insurance products purchase in Western Balkans. Authors elicit that only gross domestic product and wages rate have a positive impact while unemployment rate and interest rate is negative impact on demand of life insurance. Pant and Bahadur (2017) scrutinize the contribution of insurance in economic growth in Nepal. The research suggests that insurance positive contribute to economic growth by creating investment and managing risk in more efficient way. Ungur (2017) analyze the impact of social and economic factors on insurance sector development. Researcher dyed the fact that there is a link between economic growth and insurance sector in long term, this impact is positive and is determined by the contribution of the insurance market on GDP growth. Sawadogo et al. (2018) review the relation between the development of life insurance sector and economic growth over the period 19962011. Analysis shows that the development of life insurance has a positive effect on economic growth. Dash et al. (2018) looks into the relationship between insurance market penetration and per capita economic growth in 19 Eurozone countries. Researchers disclose that both unidirectional and bidirectional causality between insurance market penetration and per capita economic growth.

\section{Objectives of the study}

The objectives of the study are as follows:

1. To assess the growth of life insurance sector in India.

2. To assess the relationship of GDP with real premium growth rate, total investment in insurance sector and total insurance claim. 
3. To examine the effect of GDP with real premium growth rate, total investment in insurance sector and total insurance claim.

\section{Hypothesis to be tested}

$\mathrm{H}_{01}$ : There is no relationship of GDP with real premium growth rate, total investment in insurance sector and total insurance claim.

$\mathrm{H}_{02}$ : There is no significant effect of GDP with real premium growth rate, total investment in insurance sector and total insurance claim.

\section{Research Design}

The empirical work is based on insurance sector involvement for inclusive growth in India. For the purpose of analyzing the contribution of insurance sector towards growth, data has been collected only from the secondary sources for the period of 20 years (2000 to 2019) from the website of Insurance Regulatory and Development Authority (IRDA). Based on the objectives of the study, four variables are taken viz. GDP as a surrogate of economic growth as a dependent variable and independent variables are Real Premium Growth Rate, Total Investment in Insurance Sector and Total Insurance Claim . In order to analyze the data, statistical tools like descriptive statistics, correlations and regression analysis is done by SPSS 20 .

\section{Analysis and Findings}

The findings of the study are presented below.

Table 2. Registered Life Insurers in India

\begin{tabular}{cccc}
\hline \multirow{2}{*}{ Year } & \multicolumn{2}{c}{ Sector } & \multirow{2}{*}{ Total } \\
\cline { 2 - 3 } & LIC & Private & \\
\hline $2002-03$ & 1 & 12 & 13 \\
\hline $2003-04$ & 1 & 12 & 13 \\
\hline $2004-05$ & 1 & 13 & 14 \\
\hline $2005-06$ & 1 & 15 & 16 \\
\hline $2006-07$ & 1 & 16 & 17 \\
\hline $2007-08$ & 1 & 20 & 21 \\
\hline $2008-09$ & 1 & 21 & 22 \\
\hline $2009-10$ & 1 & 22 & 23 \\
\hline $2010-11$ & 1 & 23 & 24 \\
\hline $2011-12$ & 1 & 23 & 24 \\
\hline $2012-13$ & 1 & 23 & 24 \\
\hline & & &
\end{tabular}

\begin{tabular}{llll}
\hline $2013-14$ & 1 & 23 & 24 \\
\hline $2014-15$ & 1 & 23 & 24 \\
\hline $2015-16$ & 1 & 23 & 24 \\
\hline $2016-17$ & 1 & 23 & 24 \\
\hline $2017-18$ & 1 & 23 & 24 \\
\hline $2018-19$ & 1 & 23 & 24 \\
\hline
\end{tabular}

Source: IRDA

Table -2 shows that till now Insurance Regulatory and Development Authority give licenses to 24 players which includes one public life insurer and 23 private life insurers. It can be said that one public sector insurer has a dominant role play in this market with competition to private sector insurer to the growth and expansion of Indian Life insurance market.

Table 3. Life Insurance offices

\begin{tabular}{cccc}
\hline \multirow{2}{*}{ Year } & \multicolumn{2}{c}{ Sector } & \multirow{2}{*}{ Total } \\
\cline { 2 - 3 } & LIC & Private & \\
\hline 2001 & 2186 & 13 & 2199 \\
\hline 2002 & 2190 & 116 & 2306 \\
\hline 2003 & 2191 & 254 & 2445 \\
\hline 2004 & 2196 & 416 & 2612 \\
\hline 2005 & 2197 & 804 & 3001 \\
\hline 2006 & 2220 & 1645 & 3865 \\
\hline 2007 & 2301 & 3072 & 5373 \\
\hline 2008 & 2522 & 6391 & 8913 \\
\hline 2009 & 3030 & 8785 & 11815 \\
\hline 2010 & 3250 & 8768 & 12018 \\
\hline 2011 & 3371 & 8175 & 11546 \\
\hline 2012 & 3455 & 7712 & 11167 \\
\hline 2013 & 3526 & 6759 & 10285 \\
\hline 2014 & 4839 & 6193 & 11032 \\
\hline 2015 & 4877 & 6156 & 11033 \\
\hline 2016 & 4892 & 6179 & 11071 \\
\hline 2017 & 4897 & 6057 & 10954 \\
\hline 2018 & 4908 & 6204 & 11112 \\
\hline 2019 & 4932 & 6347 & 11279 \\
\hline
\end{tabular}

Source: IRDA

From Table-3 shows that the increase in LIC offices from 2186 in 2001 to 4932 in 2019 as in case of private life insurer's offices too shows a rising trend from 13 in 2001 to 6347 in 2019 which reflects that there is an unbendable competition along with LIC and private life insurers in growth of its businesses. 
Tabel 4. New Policies Issued - Life Insurers (In Lakhs)

\begin{tabular}{cccccc}
\hline \multirow{2}{*}{ Year } & \multicolumn{2}{c}{ LIC } & \multicolumn{2}{c}{ Private } & Total \\
\cline { 2 - 5 } & Investment & \% of Growth & Investment & \% of Growth & Investment \\
\hline $2004-05$ & 239.78 & -11.09 & 22.33 & 34.62 & 262.11 \\
\hline $2005-06$ & 315.91 & 31.75 & 38.71 & 73.37 & 354.62 \\
\hline $2006-07$ & 382.29 & 21.01 & 79.22 & 104.64 & 461.52 \\
\hline $2007-08$ & 376.13 & -1.61 & 132.62 & 67.4 & 508.74 \\
\hline $2008-09$ & 359.13 & -4.52 & 150.11 & 13.19 & 509.23 \\
\hline $2009-10$ & 388.63 & 8.21 & 143.62 & -4.32 & 532.25 \\
\hline $2010-11$ & 370.38 & -4.7 & 111.14 & -22.61 & 481.52 \\
\hline $2011-12$ & 357.51 & -3.47 & 84.42 & -24.04 & 441.93 \\
\hline $2012-13$ & 367.82 & 2.88 & 74.05 & -12.28 & 441.87 \\
\hline $2013-14$ & 345.12 & -6.17 & 63.60 & -14.11 & 408.72 \\
\hline $2014-15$ & 201.71 & -41.55 & 57.37 & -9.79 & 259.08 \\
\hline $2015-16$ & 205.47 & 1.86 & 61.92 & 7.92 & 267.38 \\
\hline $2016-17$ & 201.32 & -2.02 & 63.24 & 2.13 & 264.56 \\
\hline $2017-18$ & 213.38 & 5.99 & 68.59 & 8.47 & 281.97 \\
\hline $2018-19$ & 214.04 & 0.31 & 72.44 & 5.61 & 286.48 \\
\hline Source: $18 D A$ & & & & &
\end{tabular}

Source: IRDA

As the above table- 4 depicts information of new policies issued by life insurers which indicates increase in policies issued steadily by LIC from 239.78 lakhs in 2004-05 to 367.82 lakhs in 2013-14, private life insurer too have shown an rising trend up to 2008-09 in policies issued. The steady growth in policies issued cautions insurers to be innovative in capturing the business.
Relationship of GDP with Real Premium Growth Rate, Total Investment in Insurance Sector and Total Insurance Claim

From the table 5 , it is clearly shows there is no inconsistency in the results as all the variables in the data series fall within the minimum and maximum values of the series implies there exists high level of consistency. Low standard deviations in the results reveal that the actual deviation of the data from their means is nominal.

Tabel 5. Descriptive Statistics

\begin{tabular}{|c|c|c|c|c|c|c|c|c|c|}
\hline & \multirow{2}{*}{$\frac{\mathrm{N}}{\text { Statistic }}$} & \multirow{2}{*}{$\frac{\text { Min. }}{\text { Statistic }}$} & \multirow{2}{*}{$\frac{\text { Max. }}{\text { Statistic }}$} & \multirow{2}{*}{$\begin{array}{c}\text { Mean } \\
\text { Statistic }\end{array}$} & \multirow{2}{*}{$\begin{array}{l}\text { Std. Dev. } \\
\text { Statistic }\end{array}$} & \multicolumn{2}{|c|}{ Skewness } & \multicolumn{2}{|c|}{ Kurtosis } \\
\hline & & & & & & Statistic & $\begin{array}{l}\text { Std. } \\
\text { Error }\end{array}$ & Statistic & $\begin{array}{l}\text { Std. } \\
\text { Error }\end{array}$ \\
\hline GDP & 10 & 5.24 & 8.50 & 7.10 & 1.12 & -0.600 & 0.687 & -0.81 & 1.33 \\
\hline $\begin{array}{l}\text { Insurance } \\
\text { Claim }\end{array}$ & 10 & 95.69 & 99.42 & 97.70 & 1.56 & -0.065 & 0.687 & -2.31 & 1.33 \\
\hline $\begin{array}{l}\text { Total } \\
\text { Investment }\end{array}$ & 10 & 11.00 & 18.28 & 12.87 & 2.32 & 1.65 & 0.687 & 2.54 & 1.33 \\
\hline $\begin{array}{l}\text { Premium } \\
\text { Growth Rate }\end{array}$ & 10 & -5.50 & 10.10 & 4.23 & 5.86 & -0.668 & 0.687 & -1.20 & 1.33 \\
\hline $\begin{array}{l}\text { Valid N (list } \\
\text { wise) }\end{array}$ & 10 & & & & & & & & \\
\hline
\end{tabular}

Source: Computed by Author 
Tabel 6. Correlation

\begin{tabular}{|c|c|c|c|c|c|}
\hline & & GDP & $\begin{array}{l}\text { Total } \\
\text { Claim }\end{array}$ & $\begin{array}{c}\text { Total } \\
\text { Investment }\end{array}$ & $\begin{array}{c}\text { Total } \\
\text { Premium }\end{array}$ \\
\hline \multirow[t]{3}{*}{ GDP } & Pearson Correlation & 1 & 0.089 & 0.585 & $0.778^{* *}$ \\
\hline & Sig. (2-tailed) & & 0.808 & 0.076 & 0.008 \\
\hline & $\mathrm{N}$ & 10 & 10 & 10 & 10 \\
\hline \multirow{3}{*}{$\begin{array}{l}\text { Total } \\
\text { Claim }\end{array}$} & Pearson Correlation & & 1 & -0.258 & 0.492 \\
\hline & Sig. (2-tailed) & & & 0.472 & 0.149 \\
\hline & $\mathrm{N}$ & & & 10 & 10 \\
\hline \multirow{3}{*}{$\begin{array}{c}\text { Total } \\
\text { Investment }\end{array}$} & Pearson Correlation & & & 1 & 0.108 \\
\hline & Sig. (2-tailed) & & & & 0.767 \\
\hline & $\mathrm{N}$ & & & & 10 \\
\hline \multirow[t]{3}{*}{ Total Premium } & Pearson Correlation & & & & 1 \\
\hline & Sig. (2-tailed) & & & & \\
\hline & $\mathrm{N}$ & & & & 10 \\
\hline
\end{tabular}

**. Correlation is significant at the $1 \%$ level (both-tailed).

Source: Computed by Author

From the above table, it is observed that there is a positive correlation coefficient of 0.778 between the two variables, GDP and Real Premium Growth Rate, which is significant at $1 \%$ level. This coefficient value suggests a positive and strong linear relationship between them. Another observation is that there is positive correlation coefficient of 0.585 between GDP and Total Investment in Insurance Sector which is also significant at $10 \%$ level. This coefficient value suggests a positive and moderately strong linear relationship between them.

Testing for the effect of Total Insurance Claim, Total Investment and Real Premium Growth Rate on GDP: Dependent variable: GDP

The regression analysis is conducted to find the relationship between dependent variable and independent variables. Thus, this helps to identify the variation in GDP based on variation in total insurance claim, total investment in insurance sector and real premium growth rate.

To test the hypothesis representing the relationship between GDP with total insurance claim, total investment in insurance sector and real premium growth rate, multiple regression was run, the output of which result is shown in Table 7.

From table 7 , it is evident that the coefficient of determination is $88.8 \%$. It implies that the independent variables like a total insurance claim, total investment in the insurance sector, and real premium growth rate have explained up to $88.8 \%$ of the variation in GDP. Durbin-Watson value 1.291 indicates that there is no autocorrelation problem because the value is close to 2 .

Tabel 7. Model Summary

\begin{tabular}{cccccc}
\hline Model & R & R Square & Adjusted R Square & $\begin{array}{c}\text { Std. Error of the } \\
\text { Estimate }\end{array}$ & Durbin-Watson \\
\hline 1 & 0.942 & 0.888 & 0.831 & 0.461 & 1.219
\end{tabular}

Predictors: (Constant), Total Insurance Claim, Total Investment, Real Premium Growth Rate Dependent Variable: GDP

Source: Computed by Author 
Tabel 8. ANOVA

\begin{tabular}{|c|c|c|c|c|c|c|}
\hline Model & & Sum of Squares & df & Mean Square & $F$ & Sig. \\
\hline \multirow[t]{3}{*}{1} & Regression & 10.056 & 3 & 3.352 & \multirow{3}{*}{15.778} & \multirow{3}{*}{0.003} \\
\hline & Residual & 1.275 & 6 & 0.212 & & \\
\hline & Total & 11.331 & 9 & & & \\
\hline
\end{tabular}

Predictors: (Constant), Total Insurance Claim, Total Investment, Real Premium Growth Rate Dependent Variable: GDP

Source: Computed by Author

Tabel 9. Coefficients

\begin{tabular}{|c|c|c|c|c|c|c|c|c|}
\hline \multirow[t]{2}{*}{ Model } & & \multicolumn{2}{|c|}{$\begin{array}{c}\text { Unstandardized } \\
\text { Coefficients }\end{array}$} & \multirow{2}{*}{$\begin{array}{c}\begin{array}{c}\text { Standardized } \\
\text { Coefficients }\end{array} \\
\text { Beta } \\
\end{array}$} & \multirow[t]{2}{*}{$\mathrm{t}$} & \multirow[t]{2}{*}{ Sig. } & \multicolumn{2}{|c|}{$\begin{array}{c}\text { Collinearity } \\
\text { Statistics }\end{array}$} \\
\hline & & $\mathrm{B}$ & Std. Error & & & & Tolerance & VIF \\
\hline \multirow[t]{4}{*}{1} & (Constant) & 18.218 & 12.163 & & 1.498 & 0.185 & & \\
\hline & $\begin{array}{l}\text { Insurance } \\
\text { Claim }\end{array}$ & -0.149 & 0.122 & -0.206 & -1.225 & 0.266 & 0.660 & 1.515 \\
\hline & $\begin{array}{c}\text { Total } \\
\text { Investment }\end{array}$ & 0.214 & 0.071 & 0.442 & 2.997 & 0.024 & 0.861 & 1.162 \\
\hline & $\begin{array}{c}\text { Premium } \\
\text { Growth Rate }\end{array}$ & 0.159 & 0.031 & 0.832 & 5.079 & 0.002 & 0.699 & 1.431 \\
\hline
\end{tabular}

Dependent Variable: GDP

Source: Computed by Author

Based on table 8 , the $\mathrm{F}$ value is 15.778 which is significant at $1 \%$ level (p-value being 0.003 ). Hence, the overall regression model with GDP being the dependent variable and total insurance claim, total investment in insurance sector and real premium growth rate being the independent variables fits properly.

From the above table, it appears that there is no multicollinearity problem among the independent variables considered for the research (all the VIF values being less than 10). Then, the standardized beta values and the probability values provided in coefficient table are examined to determine which independent variable(s) have a significant impact on GDP.

The standardized regression coefficient values reveal that 'Real Premium Growth Rate' has such a value of $0.832(\mathrm{t}=5.079, \mathrm{p}=.002)$, which indicates a positive and significant impact (at $1 \%$ level) on the level of GDP. Another variable, 'Total Investment' reveals a coefficient value of $0.442(\mathrm{t}=2.997, \mathrm{p}=$ $.024)$, which again reveals a positive and significant impact (at 5\% level) on the level of GDP. The results can be of relevance to policy makers.

\section{MANAGERIAL IMPLICATION}

For every developing and developed country insurance sector business plays a vital role towards inclusive growth. Mainly it has play as a mediator of client side risk transfer. The major functionality of the insurance on the client side is risk transfer by paying some premium against specific uncertainty. By reducing uncertainty and unpredictability, insurance companies smoothen the economic cycle and shrink the blow of emergency situations on the micro and aggregate macro level. The insurance regulators and policy makers will observe the level of contribution of insurance to economic growth which will improve the superiority of their policy making, supervision function and regulation of the industry for better performance to meet global challenges and better contribution to economic growth. The task of insurance part in economic growth has scarcely been investigated empirically in literature as compared to banking area and stock markets. The worldwide growth of insurance and 
its influence on the government accomplishment is a clear signal of its importance in Indian economy too. This piece of information prompts us to look at this issue empirically in India.

\section{CONCLUSION}

Finally it can be concludes that the study is very useful to the policy makers as well as researchers. Firstly it is noticed that insurance policies improve by the way of insurance penetration and density in India. In the context of privatization of insurer is to affect the prospects of growth in LIC as only one public sector insurer working in India. Life Insurance will have a foundation in the financial system, the private life insurers are performing suitably, and they go on with to infiltrate the Indian market utmost. So, it can be suggest that to the policy makers to proper step to be taken to introduce some public sector insurer for LIC. From the empirical result in correlation, it is observed that there is a strong positive correlation between GDP and Real Premium Growth Rate and also GDP with Total Investment in Insurance Sector. More interesting fact in this paper obtains through multiple regressions in the effectiveness of insurance sector towards inclusive growth. The investigation reveals that two important parameter real premium growth rate and total investment in the insurance sector directly influence in the inclusive growth in the economy. For the development of the insurance market in the Indian financial system the regulator should intend the harmonization of principles and deeds and for the involvement of most excellent practices across the region. However, insurance regulators can play a key role in bridging market gaps while inspiring the surfacing of more-effective industry-led market development initiatives. In particular, policymakers and regulators can play a precious role in promoting more active involvement from industry associations to attract new talent. Policymakers and regulators should cheer the arrangement of industry wide associations as a way to harmonize the depiction of market participants.

\section{Limitation of the study}

1. The study is only based on secondary data.

2. The study is not covered all the areas of life as well as non-life insurance sector.

3. The study has done only the periods from 2000 to 2019 .

4. The study only applies few statistical tools to draw the conclusions.

\section{Suggestion for Future Research}

On the worth of this work, the study will offer input resources for further research. The insurers and reinsurers will be exposed to the trend and level of their activity towards economic growth. More research effort need to be done in the similar path by applying different time phase and different methodologies. The study recommends that the compulsory insurance policies stipulated by the insurance Act should be properly sold in the society and well publicized. Finally, it is suggested that more research should be carried out to find out more about the impact and competence of insurance segment upgrading on economic growth and development in the Indian environment. 
REFERENCES

Buric, M. N., Smolovic, J. C., Bozovic, M. L., Filipovic, A.L. (2017). "Impact of economic factors on life insurance development in Western Balkan Countries", https://doi.org/10.18045/zbefri.2017.2.331, 35(2), 331-347.

Dash, S., Pradhan, R.P., Maradana, R.P., Gaurav, K., Zaki, D.B. and Jaykumar, M. (2018). "Insurance market penetration and economic growth in Eurozone countries: Time series evidence on causality", Future Business Journal, 4(1), 50-67.

Ghosal, M. (2012). "Role of Insurance in Economic Development of India", ZENITH International Journal of Business Economics and Management Research, 2(7), 81-92.

Nejad, H. R. and Kermani, S. A. (2012). "The relation between insurance development and economic growth in Iran", Elixir International Journal, https://www.elixirpublishers.com articles 47, 9079-9087.

Olayungbo, D. O. (2015). "Effects of Life and Non-Life Insurance on Economic Growth in Nigeria: An Autoregressive Distributed Lag (ARDL) Approach”, Global Journal of Management and Business Research, 15(11), 33-40.

Pant, S. and Bahadur, F. (2017). "Contribution of Insurance in Economic Growth of Nepal", Journal of Advanced Academic Research, 4(1), 99-110.

Phutkaradze, J. (2015). "Impact of Insurance Market on Economic Growth in Post-Transition Countries, International Journal of Management and Economics, 44(1), 92-105.

Sawadogo, R., Guerineau, S. and Ouedraogo, I. M. (2018) "Life Insurance Development and Economic Growth: Evidence from Developing Countries", Journal of Economic Development, 43(2), 1-28.

Sing, K. and Gangal, V. K. (2015). "Micro Insurance in India: A Gizmo to Vehicle Economic Development \& Alleviate Poverty and Vulnerability", IOSR Journal of Economics and Finance, 6(2), 14-20.

Ungur, C. (2017). "Socio-Economic Valences of Insurance", Journal Contemporary Economy, 2(2), 112-118.

Zouhaier, H. (2014). "Insurance and economic growth", Journal of Economics and Sustainable Development, 5(12), 102-112. 